\title{
Factors Affecting Employees Performance and Retention: A Comparative Analysis of Banking and Educational Sector of Karachi
}

\author{
Sania Zafar (Corresponding author) \\ Karachi University Business School \\ University of Karachi, Karachi, Pakistan \\ Tel: 92-314-298-4349Ｅ-mail: sz.199127@gmail.com \\ Danish Ahmed Siddiqui \\ Associate Professor, Karachi University Business School \\ Karachi University Business School, University of Karachi, Karachi, Pakistan \\ Tel: 92-333-348-5884Ｅ-mail: daanish79@hotmail.com
}

Received: March 10, 2019 Accepted: April 1, 2019 Published: April 24, 2019

doi:10.5296/bms.v10i1.14537ＵRL: https://doi.org/10.5296/bms.v10i1.14537

\begin{abstract}
This study investigated the impact of core drivers of job satisfaction including promotions, increment and bonuses, supervisor's' support, career development and advancement opportunities and working conditions on two dependent variables i.e. job performance and employees retention. For this purpose a comparative study is conducted in education and banking sector of Karachi. A sample of 100 employees was collected from each sector then results were analyzed through Confirmatory Factor Analysis and Structural Equation Modeling. The results found both the education and banking sectors are different in terms of chosen human resource policies Secondly, it has been found that results are dissimilar for both sectors in terms of different hypotheses. Career development, compensation and promotions are insignificant key divers of job satisfaction for job performance. While, working conditions, compensations and co-workers are insignificant key divers of job
\end{abstract}




\section{Macrothink}

Business Management and Strategy ISSN 2157-6068

satisfaction for employees' retention. Result's implication is different for banks' managers and educational institutions' managers based on significance of coefficients however human resource policies vary in different business settings. Indeed, more the job satisfaction better chance of good employees' performance while it reduces the intention to switch and keep the human talent retained.

Keywords: Job Satisfaction, Job Performance, Employee Retention, Banking Sector, Education Sector 


\section{Introduction}

\subsection{Background to the Study}

The principal reward of any organization is its monetary compensation that it gives to the employees. This monetary compensation (pay levels and pay differentials) is a crucial element for the corporate governance. It also plays a significant role in strategy implementation (Greckhamer, 2015). Workers are promoted when their output of current job and higher-level job is compared, and it is high in the higher-level job. The employees that get quick initial promotions are most likely to get the rapid subsequent promotions. This is because the employees that have been promoted in the past have already proven their ability, so their subsequent promotion is less costly (Belzil, 2018). The compensations have always been the problem of the political economy because it is very important to understand distribution of income between the factors of production (Smith, 1776; Ricardo, 1817; Marx, 1867-1883).

In today's era, wage growth is the important factor in determining the monetary policy by major central banks (Yellen, 2015; Draghi, 2017). Compensations are revenues for workers while cost for the firms. Compensations determine the welfare of workers and it also has an impact on the decision of the firm regarding allocation of factors of production (Pasimeni, 2018). Not all employees are motivated by the monetary rewards. Rather some of the employees need intrinsic motivation to perform better. Intrinsic rewards are the psychological rewards that an employee enjoys personally with the pleasure and interest in his work (Lai, 2011). Not only the monetary rewards but the non-monetary factors like relationships with co-workers and supervisors, health care insurance and nature of work also affect the employees within the organization. Co-worker's departure can have significant impact on the left over employees depending upon the nature of relationships (스derson \& $\underline{\text { Haas, }}$ 2018).

The relationship between the employee's psychological health and workplace performance is quiet sensitive and dependent on which aspect of performance is considered (Jones, Latreille, \& Sloane, 2016). Researchers have studied that employees' increased performance is related to employee vigor. Those employees who act energizers for other employees, performs better and the employees who are receiver of this energy will also perform better because they will try to reciprocate this energy with extra effort and loyalty. Higher levels or motivation and persistence are associated with high task performance (Owens et al., 2016). Almost all the organizations use bonus systems to reward their employees to ensure better performance and productivity. Bonus programs are usually designed so that the employees may receive an additional amount other than their basic salary. These programs not only help to motivate the employees but to align individual goals with that of organization. The promotion process must be integrated with the career development systems so that employee turnover can be reduced (Campion et al., 2018). Performance incentives are a major factor that helps in improving the provision of the public sector employees (Singh \& Masters, 2018). Performance pay and bonuses also helps the employees to improve the performance and to keep their goals aligned with the organizational goals (Behrman et al., 2015). 
Not only compensation, but workplace conditions are also a main factor that contributes to job performance and satisfaction as well. Non-ergonomic and unpleasant workplace conditions are very difficult to measure and there is no specific method to analyze the cost of displeasure which is generated due to these conditions. Although the costs on the work conditions is ignored in the organizations but this significantly affects the organizational performance (Mansour, 2016). Researches have shown that in Europe work conditions have significant impact on work and mental health of the employees (Barnay, 2015). Poorly functioning work conditions have a major outcome which is depressive employees. This depression causes financial loss for employers and health loss of employees (Theorell et al., 2015).

Physical, chemical and social hazards in the workplace can result in serious injuries for the employees (Hsieh, Apostolopoulos \& Sönmez, 2015). So, compensation, benefits and workplace conditions are what contribute to employee's retention and job performance. Employee retention is an emerging concept in today's era because it is a major challenge for workforce management. Its existence can be traced back to 1900 era when the industrial engineers tried to find the reasons for the employee's interest in work (Tanwar \& Prasad, 2016). Employers must know the factors that are causing employees to leave the organization. Only in this way they can do effective retention of workers. HR must formulate an effective retention plan so that the reasons to leave the organization can be assessed (Tanwar \& Prasad, 2016). Most of the times when employees are committed to the job and they have sense of belonging towards the job, they are least expected to get tired from their jobs. Their job satisfaction is high (Peng et al., 2014). When the employee's job or experience is appraised, he/she experiences a pleasurable and positive emotional state that can be termed as job satisfaction (Alegre et al., 2016). Job satisfaction refers to "an evaluative state that expresses contentment with and positive feelings about one's job" (Judge \& Kammeyer-Mueller, 2012, p. 343). Researches have also shown that the employees that contractual or temporary employees are less satisfied from their jobs because they belong to a peripheral group who are not considered part of the corporate family (Dawson et al., 2014).

\subsection{Problem Statement}

Compensations (Christ et al., 2016), benefits (Singh \& Masters, 2018) and work environments (Mansour, 2016), have a significant impact on the organizational and individual performance. Researches have shown that if the individuals are not paid or compensated monetarily, they do not perform their tasks that are most needed by the society (Lazear, 2018). Monetary as well as non-monetary rewards are also an important factor that motivated the employees extrinsically and intrinsically to perform better (Anderson \& $\underline{\text { Haas }}, 2018$ ).

It is very important to retain the highly skilled, experienced and reliable employees because they are considered an asset for the organization. Researches have shown that highly motivated employees are more productive and perform better (Waiyaki, 2017) and motivation can be intrinsic as well as extrinsic or monetary (Compensation and Benefits). $22 \%$ of the employees in Great Britain say that their productivity is decreased because of their poor 
financial situation (Mansour, 2016). According to a research, 90\% organizations are interested in offering short-term incentives like spot awards and small group incentives to their employees so that their performance is increased (Campion et al., 2018). Not only the monetary and non-monetary rewards but work conditions are also an important factor that can affect employee's performance and satisfaction. Work injuries and chronic workplace environments can cause increased stress levels in employees which can hamper their productivity. Time loss, administrative expenses incurred on investigation of accident and the litigation expenses (legal penalties etc.) will cause serious damage to revenue of firm and employee performance as well (Mansour, 2016).

\subsection{Gap Analysis}

Researches showed that enhancing the employee's motivation results in better performance of employees (Kiruja \& Mukuru, 2013). This implies that if employees are motivated then they perform well. Now question is that if employees are motivated by compensations, non-monetary rewards or workplace conditions so that they can enhance their performance. So, we are investigating some other factors other than monetary benefits and compensations that can contribute to performance and motivation. Employees are motivated by intrinsic rewards (Dickson, 1973) while others need extrinsic and monetary rewards (Froese, 2018) and their performance is improved. Employees can be motivated by both factors (Riggio, 2013).

The relationship of job satisfaction and performance was studied in a setting of Afghani and Pakistani Capital cities only (Gul et al., 2018). Sample comprised of the teaching staff only. We therefore analyzed the relationship with different demographics and different sample size. We took the sample from banking sector so that more generalizability may become possible. Work conditions also have a significant impact on job satisfaction and this effect was also studied earlier but the sample selection was not random (Tejeda, 2014). This created bias and hence results cannot be generalized. So, we investigated the relationship with random sampling hence there was less chances of bias. The relationship between the employee retention and compensation was studied in manufacturing and services sector of Pakistan (Khalid, 2018). Therefore, goal of this study is to examine same variables in banking industry as well. Changing the industry will help in generalizing the results to whole population. (Kossivi et al., 2016) investigated different factors that can contribute to employee's retention, but the studies lack the specific industry and the type of business from which the employees belong to. So, we are studying the specific sector and industry so that organizations know how to improve their retention capabilities.

Literature shows that motivated employees performs better and stay more loyal to the organization. Workplace conditions also have a significant impact on retaining the employees and good work conditions tends to increase the employee's performance. But sector specific studies need to be conducted so that generalizability can be achieved. Moreover, the sample size needed to be increased because small sample size can create bias. 


\subsection{Research Objectives}

The aim of this study is to examine the effects of different dimensions of job satisfaction like compensations, co-workers, supervisors, career development, health care insurance, working conditions and increment \& bonuses on the employee's performance and employee's retention. Different studied have been conducted in which the effects of compensation and working conditions was studied on performance and retention. This study has been conducted to test the significant impact of different dimensions of job satisfaction like workplace conditions on performance and retention of employees. If the employees within an organization are stressed due to compensations, work conditions, supervisors, co-workers or increments, their productivity and performance may decrease. This implies that less satisfied employees tend to leave the organization very soon and their loyalty to the organization is also at stake if they are not satisfied with their jobs because anger and frustration can affect their productivity. Satisfied employees are those employees whose jobs are being appraised by their supervisors or top management. This job satisfaction in employees in turn has a significant impact on retention and performance.

This research is aimed to study the effects of career development, compensations, co-workers working conditions, health care insurance, promotions, increment and bonuses, supervisors on job performance and employee retention.

\subsection{Research Questions}

What is impact of Career Development on Job Performance?

What is impact of Co-Workers on Job Performance?

What is impact of Compensations on Job Performance?

What is impact of Working Condition on Job Performance?

What is impact of Healthcare Insurance on Job Performance?

What is impact of Increment and Bonuses on Job Performance?

What is impact of Promotion on Job Performance?

What is impact of Supervisor on Job Performance?

What is impact of Career Development on employees' retention?

What is impact of Co-Workers on employees' retention?

What is impact of Compensations on employees' retention?

What is impact of Working Condition on employees' retention?

What is impact of Healthcare Insurance on employees' retention?

What is impact of Increment and Bonuses on employees' retention?

What is impact of Promotion on employees' retention?

What is impact of Supervisor on employees' retention? 
1.6 Significance of Study

In contemporary organizations, adverse psychological factors and work conditions results in elevated risk of depressive symptoms so it is very important to study the workplace conditions (Theorell, 2015). Organizations need to provide better work conditions to its employees and for this reason; it needs to understand the core reasons that provoke the stress in employees (Mansour, 2016). This is because the stressed employees are less engaged, less productive and more absenteeism is observed (Dyble, 2014) and employee retention becomes difficult in case of stressed employees. Employee retention is no doubt a largest cost for organizations yet it is most unknown cost (Tanwar \& Prasad, 2016). This is why we are studying the effects of compensation, benefits and work conditions on job performance and employee retention.

\section{Literature Review}

\subsection{Compensation and Benefits}

Organizations are facing a major decision-making problem whether to rewards the employees financially or non-financially so that employees can become contended and perform better. Researches have shown that financial rewards constitute almost $40 \%$ of payroll budgets. Extrinsic motivations are the monetary and financial rewards like salary increment or bonuses that are given to employees so that they can perform better for the achievement of organizational goals (Karikari, 2018). Different researchers have found that employee's motivation does not solely depend on the monetary rewards and benefits (Dickson, 1973). Researches have shown negative relationship of compensation control with job performance. Employee's behavior and performance is mainly affected by the compensation and hence we are investigating this effect on employee's performance (Christ, 2016). This means that compensations and monetary benefits have a significant impact on employee's performance and employees are retained if they are provided with full monetary benefits (Khalid, 2018). Chong \& Law, 2016 conducted study in Australia and 120 employees of Australian Manufacturing Firms were surveyed. The results were in accordance to the Agency theory that due to compensation schemes, employees put their efforts and in turn effects job performance.

Researches have shown that if the individuals are not paid or compensated monetarily, they do not perform their tasks that are most needed by the society (Lazear, 2018). Another study was conducted in 10 German hospitals and data was collected from $n=136$ nurses. Results indicated that selective optimization with compensation helps in maintaining quality of performance so that nurses can forget the work load (Baethge, Müller \& Rigotti, 2015). Data was also collected from 207 individuals from an international hospital and there was a significant and strong positive correlation between compensation and job performance (Do, 2018). LMX relationships are also partially based on the culture (Furunes, Mykletun, Einarsen, \& Glas $\varnothing, 2015)$. LMX theory is very important to determine the follower's performance and job satisfaction and is one of the major topics being studied in literature of 
leadership. According to a study not only the leader-member exchange have significant impact over turn over intentions but also on the objective performance of the followers (Gutermann et al., 2017).

Researches have shown that if organizations provide healthcare insurance to their employees, employee productivity increases. According to some researchers, there exists a direct relationship between labor productivity and health care insurance while some researchers proposes that it only has indirect benefits (Devaraj \& Patel, 2017). Compensation controls are often used to direct the employee's attention towards a specific task or variety of tasks. Incentives are the major factor that contributes to employee's self-interest and it motivates the employees to put more effort. A task that is not rewarded or less rewarded does not seek employee's effort and performance (Christ, Emett, Tayler \& Wood, 2016). 125 under graduate students were participants in a study and results indicated that compensation controls result in lower performance (Christ et al., 2016).

A study conducted in South Asian hospital's nursing staff also showed that compensation has a significant impact on job satisfaction. 247 nurses from India, Pakistan and Sri Lanka were surveyed using questionnaires and it showed that compensation is positively associated with job satisfaction (Shah et al., 2018). A study conducted in Japan showed that merit-based monetary rewards are directly and strongly correlated to job satisfaction. In this study, 636 employees were interviewed for a period of 12 months (Froese et al., 2018).

A study conducted in services and manufacturing sectors of Pakistan showed that to enhance the employee retention, employers must increase employee's participation and compensations. 1054 employees from services and manufacturing sector of Pakistan were surveyed for this study and results indicated that if compensation is increased, employees can perform better (Khalid \& Nawab, 2018). Another study shows that cut in current salary and direct benefits are positively associated with cut in job tenure. This implies that employee retention decreases if there would be a decrease in compensation and benefits. Data was collected over the period of 30 years in this study and average elasticities of job tenure were measured (Falk \& Karamcheva, 2018). A review research also shows the same results that good compensation plans, benefits and rewards have a significant impact on employee retention and rewards strategies should be designed very vigilantly (Bussin, 2018).

\subsection{Work Conditions}

The reduced ergonomic work conditions have short and long run effects on employee's health and firm's profits (Mansour, 2016). The adverse work conditions have a significant impact on the well-being and mental health of the workers (Angerer \& Weigl, 2015). A study conducted among 16926 employees who were participating in worksite wellness program in Colorado showed that workplace safety has a significant impact on performance. The chronic workplace conditions resulted in absenteeism and decreased performance. Employers must be focusing on reducing the risk of workplace injuries and promote healthy working conditions (Jinnett et al., 2017). Study conducted in US, surveyed 292 managers and employees of 
online networking service. Results showed that even in adverse workplace conditions, employees' performance can increase in presence of spiritual well-being (Tejeda, 2014). In another study, 27 employees/housekeepers of Latina Hotels were interviewed and results showed that all of them were exposed to workplace hazards and poor work conditions due to which employees were stressed and performance was affected (Hsieh, 2016). In Eskisehir, metal industry employees were surveyed and critical environmental conditions were investigated. Total 92 measurements were taken and it was found that exogenous factors like poor workplace conditions contribute in decreased performance of employees (Kahya et al., 2018).

A study conducted in healthcare industry of Madhya Pradesh revealed that work conditions (Participative Climate (PC), Role Performance (RP)) have a significant impact on employee's retention. 1010 employees of different public and private hospitals were surveyed and results were analyzed (Jadon \& Upadhyay, 2018). Workplace conditions are also significantly related to job satisfaction and employee's retention. 692 registered nurses working in a university hospital were surveyed and results indicated that job satisfaction increases with better workplace conditions and employee retention increases (Mizuno et al., 2018).

\subsection{Job Performance and Retention}

Job performance is a key performance indicator of success organizations and it is widely acceptable (Masa'deh et al., 2017). Job performance is affected by the hindrance stressors because they bring unpleasant emotions of anger and frustrations. This makes employees less motivated, less confident and disengaged (LePine et al., 2016). Job performance can be increased by implementing behavior focused strategies. These strategies help in stimulation of desirable behaviors (Breevaart et al., 2015).

Preservation of knowledge can be done by the employee retention so that the embedded knowledge of the acquired firm can be transferred to combined firm. According to a study in Tokyo, employee voluntary turnover is indirectly and positively related to job satisfaction. 636 employees were surveyed for this study and results showed that with the increase in job satisfaction, employee voluntary turnover is decreased and hence employee retention increases (Froese et al., 2018). Employee retention is associated with knowledge transfer. This is because employees who possess special knowledge are very critical for sustainable growth and getting competitive advantage (Ahammad et al., 2016). Retention basically can be described as when employees decide to work and stay in any organization. Employee retention is when organization focuses on how to keep the employees who have contributions towards the organizational success.

Job performance has been studied also in the health care industry and in nursing staff, affective commitment is positively related to the high job performance (Sharma \& Dhar, 2016). Researches have shown that Job satisfaction has no significant impact on job performance. A study conducted in Ilam, Iran interviewed 208 nurses working in teaching hospitals and results found no significant relation between job satisfaction and performance 
(Safarpour et al., 2018). Another study conducted in the universities of Kabul and Pakistan showed that Job satisfaction is a mediator between the PE fit and job performance. Total 56 universities took part in the studies out of which 14 were of Islamabad and 42 were of Kabul (Gul et al., 2018). 100 employees from manufacturing industry of Malaysia reported that career development (a factor of job satisfaction) is negatively associated with the employee turnover intention and employee retention is high (Chin, 2018). A study was conducted in hotel industry of Thailand in which 403 employees of thirty hotels participated. This study supported the fact that if the job satisfaction is high, employee retention would be high (Ashton, 2017).

\subsection{Hypotheses}

$\mathrm{H}_{1}$ : Career Development has a significant impact on Job Performance

$\mathrm{H}_{2}$ : Co-Workers have a significant impact on Job Performance

$\mathrm{H}_{3}$ : Compensations have a significant impact on Job Performance

$\mathrm{H}_{4}$ : Working Condition has a significant impact on Job Performance

$\mathrm{H}_{5}$ : Healthcare Insurance has significant impact on Job Performance

$\mathrm{H}_{6}$ : Increment And Bonuses have a significant impact on Job Performance

$\mathrm{H}_{7}$ : Promotion has significant impact on Job Performance

H8: Supervisor has significant impact on Job Performance

H9: Career Development has a significant impact on employees' retention

$\mathrm{H}_{10}$ : Co-Workers have a significant impact on employees' retention

$\mathrm{H}_{11}$ : Compensations have a significant impact on employees' retention

$\mathrm{H}_{12}$ : Working Condition has a significant impact on employees' retention

$\mathrm{H}_{13}$ : Healthcare Insurance has significant impact on employees' retention

$\mathrm{H}_{14}$ : Increment And Bonuses have a significant impact on employees' retention

$\mathrm{H}_{15}$ : Promotion has significant impact on employees' retention

H16: Supervisor has significant impact on employees' retention

\section{Methodology}


INDEPENDENT VARIABLES

DEPENDENT VARIABLES

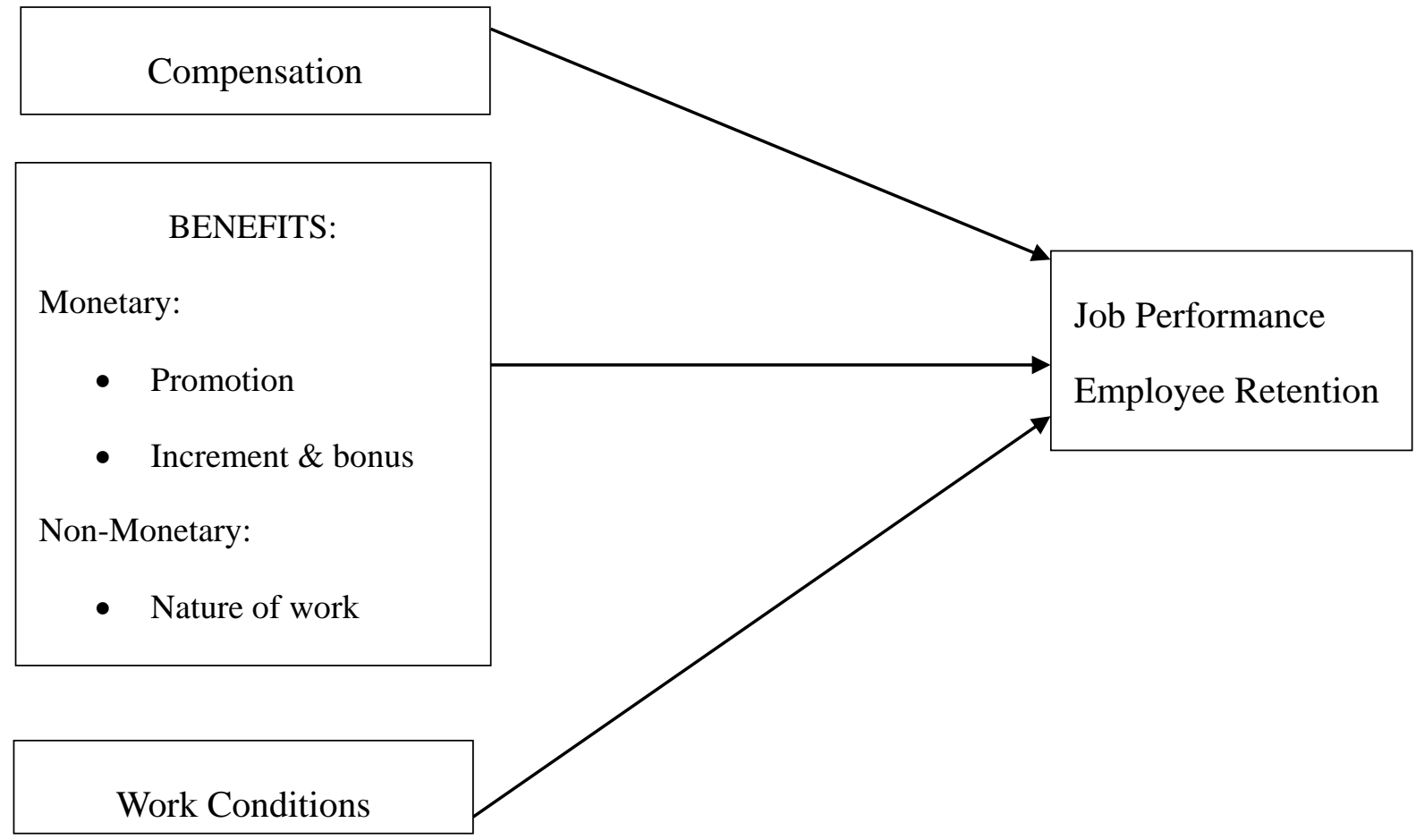

Fig. 1. Theoretical Framework

This research is conducted to study the effects of independent variables (compensation, benefits and work conditions) on dependent variables (job performance and employee retention) while taking job satisfaction as a mediator in the case.

\subsection{Population and Sample}

In our study, we used convenience sampling. Data was collected from banking and educational sector of Karachi. A sample of 50 respondents is enough to run a regression analysis (Williams, 2007). So, our sample consisted of 100 individuals from each sector banking and education.

\subsection{Techniques and Procedures}

There were 3 main sections of our questionnaire that were adapted from (Edith, Iravo, Nanusonge 2015; Koitalek 2016; Nilgun 2017; Msengeti \& Obwagi 2015; Rizwan 2014). Five response alternatives were used to fill the questionnaire according to Likert-Scale $(1=$ Not at all or strongly agree, 2 = Little extent or Agree, 3 = Moderate extent or Not sure, $4=$ Great extent or Disagree, and 5 = Very great extent or Strongly disagree) (Chin, 2018). Reliability was tested through Cronbach's Alpha (Cronbach \& Shavelson, 2004). The variable value of more than 0.7 is preferred however 0.6 is also considered reliable (Chin, 2018). For Reliability analysis, confirmatory factor analysis, discriminant validity, convergent validity and Partial Least Square, Smart PLS is used. 


\section{Macrothink}

\section{Results of Study}

Table 1. Descriptive Statistics (Demographic Profile)

\begin{tabular}{|l|l|l|}
\hline Demographic Profile & $\begin{array}{l}\text { Banks' Employees } \\
(\text { Percentage) }\end{array}$ & $\begin{array}{l}\text { Education Sector's } \\
\text { Employees (Percentage) }\end{array}$ \\
\hline Male & $63 \%$ & $52.0 \%$ \\
\hline Female & $37 \%$ & $48.0 \%$ \\
\hline Bachelor's Degree Holders & $41 \%$ & $11.0 \%$ \\
\hline Certificate Holders & - & $5.0 \%$ \\
\hline Master's Degree Holders & $53 \%$ & $62.0 \%$ \\
\hline Intermediate Certificate Holders & $6 \%$ & $2.0 \%$ \\
\hline PhD/MS Degree Holders & - & $20.0 \%$ \\
\hline Contractual Employees & $13 \%$ & $37.0 \%$ \\
\hline Permanent Employees & $87 \%$ & $63.0 \%$ \\
\hline 1 - 5 years & $61.0 \%$ & $49.0 \%$ \\
\hline 10 years or above & $21.0 \%$ & $29.0 \%$ \\
\hline $5-10$ years & $18.0 \%$ & $22.0 \%$ \\
\hline
\end{tabular}

It is posited in above table that $63 \%$ male \& $37 \%$ female respondents from banks and $52 \%$ male \& $48 \%$ female respondents form educational institutions participated in the survey. Most of them are Bachelor's degree holders (41\% from banks) and Master's degree holders (53\% from banks and $62 \%$ from educational institutions). In education sector, it is noted that $20 \%$ respondents are $\mathrm{M} / \mathrm{S}$ or PhDs. Ratio of contractual employees (37\%) is higher in education sector as compare to banks (13\%). On the other hand most of the employees (61\% from banks \& $49 \%$ from education sector) hold 1- 5 years of experience.

Table 2. Descriptive Statistics (Items Mean \& Std. Deviation)

\begin{tabular}{|c|c|c|c|c|c|c|}
\hline \multirow[t]{2}{*}{ Items } & \multicolumn{3}{|c|}{$\begin{array}{l}\text { Banks' } \\
\text { (Percentage) }\end{array}$} & \multicolumn{3}{|c|}{$\begin{array}{l}\text { Education Sector's } \\
\text { Employees (Percentage) }\end{array}$} \\
\hline & Mean & Std.D & S.E & Mean & Std. D & S.E \\
\hline \multicolumn{7}{|l|}{ COMPENSATION } \\
\hline $\begin{array}{l}\text { The most important factor that makes me perform } \\
\text { well at my job is when my salary is paid regularly. }\end{array}$ & 2.91 & .130 & 1.303 & 3.59 & .114 & 1.138 \\
\hline $\begin{array}{l}\text { My organization/ institution's pay policy helps } \\
\text { attract and retain high performing employees }\end{array}$ & 2.40 & .125 & 1.247 & 2.37 & .136 & 1.361 \\
\hline I am satisfied with the level of pay I receive & 2.73 & .125 & 1.254 & 3.62 & .114 & 1.135 \\
\hline \multicolumn{7}{|l|}{ PROMOTION } \\
\hline $\begin{array}{l}\text { I believe that promotion is rewarded on fair basis to } \\
\text { employees }\end{array}$ & 2.79 & .117 & 1.166 & 3.42 & .117 & 1.174 \\
\hline $\begin{array}{l}\text { The targets set for promotions are realistic and also } \\
\text { linked with career development. }\end{array}$ & 2.74 & .129 & 1.292 & 3.50 & .127 & 1.267 \\
\hline
\end{tabular}




\section{INCREMENT AND BONUSES}

\begin{tabular}{|l|l|l|l|l|l|l|}
\hline $\begin{array}{l}\text { The amount of increment and bonuses offered by } \\
\text { organization are competitive with the market which } \\
\text { allows me to stay in this organization. }\end{array}$ & 2.47 & .127 & 1.267 & 3.92 & .109 & 1.089 \\
\hline $\begin{array}{l}\text { The increment and bonuses provided helps to } \\
\text { perform well on the job. }\end{array}$ & 2.40 & .134 & 1.341 & 3.43 & .137 & 1.373 \\
\hline $\begin{array}{l}\text { Overall, I am satisfied with the increment and bonus } \\
\text { provided. }\end{array}$ & 2.73 & .128 & 1.278 & 3.94 & .115 & 1.153 \\
\hline
\end{tabular}

HEALTHCARE INSURANCE

\begin{tabular}{|l|l|l|l|l|l|l|}
\hline $\begin{array}{l}\text { Health care insurance, where I work are competitive } \\
\text { with the market. }\end{array}$ & 2.75 & .123 & 1.234 & 3.59 & .111 & 1.111 \\
\hline $\begin{array}{l}\text { Insurance benefit offered by my organization is a } \\
\text { factor that allows me to stay in this organization. }\end{array}$ & 2.44 & .106 & 1.057 & 3.58 & .118 & 1.182 \\
\hline $\begin{array}{l}\text { My organization's insurance plan helps me to } \\
\text { perform without any stress }\end{array}$ & 2.51 & .108 & 1.078 & 3.69 & .116 & 1.161 \\
\hline
\end{tabular}

\section{CO-WORKERS}

$\begin{aligned} & \text { The task-based assistance from my co-worker } \\ & \text { increases the positive work attitude. }\end{aligned}$
$\begin{aligned} & \text { My colleagues and I are satisfied with each other's } \\ & \text { work. }\end{aligned}$

SUPERVISOR

$\begin{aligned} & \text { My manager/ head gives fair feedback on my } \\ & \text { performance standards }\end{aligned}$
$\begin{aligned} & \text { My manager/ head is open to suggestion which } \\ & \text { allows me to stay in this organization. }\end{aligned}$

CAREER DEVELOPMENT AND ADVANCEMENT

Organization/ institution uses a systematic process for identifying employee development needs and implementing solutions

Organization/ institution provides adequate opportunity for training and professional development.

There is an equal opportunity for career development and advancement within my organization.

\section{WORKING CONDITIONS}

\begin{tabular}{|c|c|c|c|c|c|c|}
\hline $\begin{array}{l}\text { The availability of tools and equipment (including } \\
\text { computers) in my immediate work area are adequate } \\
\text { and helpful in performing well }\end{array}$ & 2.23 & .098 & .983 & 2.34 & .105 & 1.047 \\
\hline $\begin{array}{l}\text { Overall, the physical conditions of my organization/ } \\
\text { institution, location, workplace environment are }\end{array}$ & 2.22 & .097 & .970 & 2.64 & .124 & 1.243 \\
\hline
\end{tabular}




\begin{tabular}{|c|c|c|c|c|c|c|}
\hline adequate for good performance. & & & & & & \\
\hline $\begin{array}{l}\text { On my job, I have sufficient opportunities to use my } \\
\text { personal talents and use my initiatives. }\end{array}$ & 2.22 & .084 & .836 & 2.94 & .134 & 1.340 \\
\hline $\begin{array}{l}\text { The Management does a good job of keeping me } \\
\text { informed about matters affecting me. }\end{array}$ & 2.35 & .096 & .957 & 3.29 & .120 & 1.200 \\
\hline \multicolumn{7}{|l|}{ EMPLOYEES PERFORMANCE } \\
\hline My work in this practice has met my expectations & 2.67 & .097 & .975 & 2.97 & .126 & 1.259 \\
\hline Overall, I am pleased with my work & 2.90 & .093 & .927 & 2.85 & .130 & 1.298 \\
\hline Overall, I am satisfied in my current practice & 2.69 & .111 & 1.107 & 2.84 & .133 & 1.331 \\
\hline $\begin{array}{l}\text { My performance is better than that of my colleagues } \\
\text { with similar qualifications. }\end{array}$ & 2.86 & .096 & .964 & 2.66 & .125 & 1.249 \\
\hline $\begin{array}{l}\text { I am satisfied with my performance because it is } \\
\text { mostly good. }\end{array}$ & 2.70 & .114 & 1.142 & 2.39 & .125 & 1.254 \\
\hline $\begin{array}{l}\text { My performance is better than that of employees } \\
\text { with similar qualifications in other organizations. }\end{array}$ & 2.65 & .105 & 1.048 & 2.63 & .125 & 1.253 \\
\hline \multicolumn{7}{|l|}{ EMPLOYEES RETENTION } \\
\hline I often think about quitting. & 2.22 & .125 & 1.252 & 3.13 & .139 & 1.390 \\
\hline $\begin{array}{l}\text { It is likely that I will actively look for a new job next } \\
\text { year. }\end{array}$ & 2.20 & .121 & 1.206 & 2.97 & .140 & 1.396 \\
\hline I often think of changing my job. & 2.27 & .130 & 1.302 & 2.80 & .144 & 1.435 \\
\hline
\end{tabular}

Above table posited that mean and std. deviation values for all core divers of job satisfaction and two dependent variables job performance and employees retention. It has been found that mean values of core divers of job satisfaction and two dependent variables job performance and employees retention for banks' employees range from 2.00 to 2.91 along with Std. Deviation values 0.84 to 1.30 however responses are within range of average score. On the other hand, mean values of core divers of job satisfaction and two dependent variables job performance and employees retention for education sectors' employees range from 1.87 to 3.94 along with std. deviation 1.05 to 1.44 however responses are dispersed widely and range below average to above average. On the other hand educational institutions' employees are more intended to switch their jobs than bank employees owing to the high mean values even data dispersion in high there.

Table 3. Sample T-Test (Compare Group Mean)

\begin{tabular}{|l|l|l|l|l|}
\hline Variables of Study (Comparison) & $\begin{array}{l}\text { Banks' } \\
\text { Employees }\end{array}$ & $\begin{array}{l}\text { Education } \\
\text { Institutions } \\
\text { Employees }\end{array}$ & \multicolumn{2}{|l|}{ Compare Mean } \\
\hline Statistics & $\begin{array}{l}\text { Group } \\
\text { Mean }\end{array}$ & Group Mean & T-value & P-value \\
\hline Compensation & 2.680 & 3.193 & 1.374 & .243 \\
\hline
\end{tabular}




\begin{tabular}{|l|l|l|l|l|}
\hline Promotion & 2.765 & 3.460 & 4.632 & .033 \\
\hline Increment and Bonuses & 2.533 & 3.763 & 3.725 & .055 \\
\hline Healthcare Insurance & 2.566 & 3.620 & 0.175 & .676 \\
\hline Co-Workers & 2.320 & 2.955 & 1.126 & .290 \\
\hline Supervisor And & 2.133 & 2.933 & 10.39 & .001 \\
\hline $\begin{array}{l}\text { Career } \\
\text { Advancement }\end{array}$ & & 2.590 & 4.683 & .032 \\
\hline Working Conditions & 2.255 & 2.802 & 11.22 & .001 \\
\hline Employees Performance & 2.255 & 2.723 & 4.041 & .046 \\
\hline Employees Retention & 2.770 & 2.966 & 0.196 & .658 \\
\hline
\end{tabular}

Table 3 posited that in response to the job satisfaction core divers promotions, increment and bonuses, supervisor's' support, career development and advancement opportunities and working conditions both sectors' employees are significantly different from each other. While both sector employees also differ in their job performance scale. These results clearly indicating dynamics of education sector and banking sector differ in terms of human resource management policies.

\subsection{Structural Equation Modeling}

To test the study hypothesis we have used the structural equation model (SEM) whereas the testing has been gone through Smart PLS software. Moreover, to evaluate the indirect and direct effects of all the constructs the testing was done. The use of (SEM) structural equation model has been observed to be a foremost procedure that has been used below different regression models and methods (Barron \& Kenny, 1986). It used to evaluate the structural relationship between exogenous and endogenous variables. It includes factor analysis and multivariate analysis. Moreover, the equation of regression targets at explaining each construct to assess the cause and effect relationship while all of the factors in the causal model could demonstrate their cause and effect at exact time. Likewise, the idea of using this model ensures to apply technique of bootstrapping which has been viewed as reasonable for both small and large sample size and does not require any kind of indirect effect (Hayes, 2013). In order to check the all direct and indirect effects, a technique has been implemented which is known as bootstrapping (Shrout \& Bolger, 2002).

\subsection{Measurement of Outer Model}

The goal of measure of fit in the measurement model is to study about the reliability and validity of the instrument and to check its reliabity and validity we perform test of convergent validity and discriminant validity in software naming Smart PLS.

\subsection{Composite Reliability}

Reliability of the measurement instruments was evaluated using composite reliability. All the values were above the normally used threshold value i.e. 0.70 . This is the accepted reliability value range. Estimation of reliability can be done by degree of constancy that lies amongst 


\section{Macrothink}

various variables (Hair , 2010). Below is the table of composite reliability.

Table 4. Composite Reliability

\begin{tabular}{|l|l|}
\hline Variables & Composite Reliability \\
\hline Career Development & 0.816 \\
\hline Co-Workers & 0.793 \\
\hline Compensation & 0.734 \\
\hline Employee Performance & 0.946 \\
\hline Employee Retention & 0.756 \\
\hline Healthcare Insurance & 0.814 \\
\hline Increment and Bonuses & 0.837 \\
\hline Promotion & 0.789 \\
\hline Supervisor & 0.720 \\
\hline Working Conditions & 0.816 \\
\hline
\end{tabular}

\subsection{Factor Loadings Significant}

Below is the mentioned table of (CFA) confirmatory factor analysis with the loadings. Construct with the loading of .5 are consider as strong loading variables whereas the constructs with the loading of below .5 are considered as less are better to be removed from the table.

Table 5. Factor Loadings

\begin{tabular}{|l|l|l|l|l|l|l|l|}
\hline Sector & \multicolumn{5}{l|}{ Banks' Employees } & \multicolumn{3}{l|}{ Education Institutions' Employees } \\
\hline Variables & Constructs & Item loading & T-value & P-Value & $\begin{array}{l}\text { Item } \\
\text { loading }\end{array}$ & T-value & P-Value \\
\hline Compensation & C-1 & 0.887 & 15.483 & 0.000 & 0.882 & 15.671 & 0.000 \\
\hline & C-3 & 0.753 & 4.949 & 0.035 & 0.856 & 8.445 & 0.000 \\
\hline Promotion & P-1 & 0.938 & 42.995 & 0.000 & 0.797 & 2.464 & 0.014 \\
\hline & P-2 & 0.933 & 39.909 & 0.000 & 0.910 & 3.398 & 0.001 \\
\hline Increment and Bonuses & IB-1 & 0.888 & 25.615 & 0.000 & 0.936 & 44.222 & 0.000 \\
\hline & IB-2 & 0.889 & 22.010 & 0.000 & 0.708 & 7.518 & 0.000 \\
\hline & IB-3 & 0.781 & 9.956 & 0.000 & 0.907 & 29.910 & 0.000 \\
\hline Healthcare Insurance & HI-1 & 0.751 & 10.782 & 0.000 & 0.903 & 3.572 & 0.000 \\
\hline & HI-2 & 0.846 & 24.560 & 0.000 & 0.815 & 3.873 & 0.000 \\
\hline & HI-3 & 0.856 & 22.235 & 0.000 & 0.872 & 3.689 & 0.000 \\
\hline Co-Workers & CW-1 & 0.923 & 51.410 & 0.000 & 0.902 & 43.019 & 0.000 \\
\hline
\end{tabular}




\begin{tabular}{|l|l|l|l|l|l|l|l|}
\hline & CW-2 & 0.897 & 25.953 & 0.000 & 0.888 & 21.664 & 0.000 \\
\hline Supervisor & S-1 & 0.785 & 4.897 & 0.000 & 0.919 & 7.387 & 0.000 \\
\hline & S-2 & 0.791 & 4.054 & 0.000 & 0.550 & 2.588 & 0.010 \\
\hline Career Development and Advancement & CDA-1 & 0.927 & 30.661 & 0.000 & 0.961 & 3.854 & 0.000 \\
\hline & CDA-3 & 0.910 & 17.905 & 0.000 & 0.888 & 4.287 & 0.000 \\
\hline Working Conditions & WC-1 & 0.787 & 10.708 & 0.000 & 0.762 & 9.759 & 0.000 \\
\hline & WC-2 & 0.906 & 36.001 & 0.000 & 0.820 & 11.165 & 0.000 \\
\hline & WC-3 & 0.702 & 7.981 & 0.000 & 0.887 & 43.321 & 0.000 \\
\hline Employees Performance & EP-1 & 0.862 & 24.197 & 0.000 & 0.898 & 22.452 & 0.000 \\
\hline & EP-2 & 0.885 & 28.516 & 0.000 & 0.946 & 46.625 & 0.000 \\
\hline & EP-3 & 0.889 & 35.843 & 0.000 & 0.923 & 36.344 & 0.000 \\
\hline Employees Retention & ER-1 & 0.930 & 37.049 & 0.000 & 0.915 & 38.061 & 0.000 \\
\hline & ER-2 & 0.964 & 93.288 & 0.000 & 0.877 & 23.581 & 0.000 \\
\hline & ER-3 & 0.955 & 57.237 & 0.000 & 0.944 & 68.705 & 0.000 \\
\hline
\end{tabular}

It has been posited that that all core drivers of job satisfaction including promotions, increment and bonuses, supervisor's' support, career development and advancement opportunities and working conditions of both sectors' employees loading values more than 0.70 except EP-4 (0.695) and WC-3 (0.699) for bank employees and S-2 (0.639) for education sector employees thus it supports strong loading. While to the both dependent variables job performance and employees retention loading values are more than 0.70 thus it supports strong loading also On the other hand $t$ values for all independent and dependent variables are supported more than 1.96 for all constructs along with sig. values less than 0.05 .

\subsection{Convergent Validity}

The table below also indicates about the reliability and validity of the interrelated variables. The notion of reliability assists to demonstrate about the consistency among the multiple variables and has been measured with the help of the PLS software. The study has been doing the reliability test by linking it with the Cronbach's alpha with the objective to measure the reliability of the scale. The present study has also followed the Cronbach approach to see the reliability of the scale which should always be higher than the value of 0.7 to ensure higher internal consistency.

Convergent validity is the level of agreement in at least two measures of a similar construct (Carmines and Zeller, 1979). Convergent validity was assessed by inspection of variance mined for each factor (Fornell and Larcker, 1981). Conferring to Fornell and Larcker (1981), if the, variance extracted value is greater than 0.5 then convergent validity is established and the result is drawn that the loadings are good but less than 0.5 are termed as less effective for the study.

Following table displays the result. 
Table 6. Convergent Validity

\begin{tabular}{|c|c|c|c|c|c|c|}
\hline \multirow{2}{*}{$\begin{array}{l}\text { Sector } \\
\text { Variables }\end{array}$} & \multicolumn{3}{|l|}{ Banks' Employees } & \multicolumn{3}{|l|}{$\begin{array}{l}\text { Education } \\
\text { Employees }\end{array}$} \\
\hline & Cronbach's Alpha & Composite Reliability & $(\mathrm{AVE})$ & $\begin{array}{l}\text { Cronbach's } \\
\text { Alpha }\end{array}$ & $\begin{array}{l}\text { Composite } \\
\text { Reliability }\end{array}$ & $(\mathrm{AVE})$ \\
\hline Career Development & 0.816 & 0.916 & 0.844 & 0.696 & 0.769 & 0.627 \\
\hline Co-Workers & 0.793 & 0.906 & 0.828 & 0.752 & 0.890 & 0.801 \\
\hline Compensation & 0.734 & 0.803 & 0.674 & 0.677 & 0.860 & 0.755 \\
\hline Employee Performance & 0.946 & 0.965 & 0.903 & 0.900 & 0.937 & 0.833 \\
\hline Employee Retention & 0.756 & 0.858 & 0.669 & 0.839 & 0.898 & 0.747 \\
\hline Healthcare Insurance & 0.814 & 0.890 & 0.729 & 0.817 & 0.891 & 0.734 \\
\hline Increment And Bonuses & 0.837 & 0.892 & 0.675 & 0.854 & 0.891 & 0.629 \\
\hline Promotion & 0.789 & 0.765 & 0.620 & 0.644 & 0.841 & 0.727 \\
\hline Supervisor & 0.720 & 0.843 & 0.644 & 0.600 & 0.732 & 0.682 \\
\hline Working Conditions & 0.816 & 0.916 & 0.844 & 0.770 & 0.865 & 0.682 \\
\hline
\end{tabular}

Table 5 posited that all core divers of job satisfaction (promotions, increment and bonuses, supervisor's' support, career development and advancement opportunities and working conditions) and two dependent variables job performance and employees retention are reliable because of mentioned Cronbach's Alpha values $>0.70$.

\subsection{Discriminant Validity}

Discriminate validity can be defined as any single construct when differs from other constructs in the model (Carmines and Zeller, 1979). Discriminate validity results are satisfactory when the constructs are having an AVE loading more than 0.5 which means that minimum $50 \%$ of variance was took by the construct (Chin, 1998). Discriminate validity is established if the elements which are in diagonal are significantly higher than those values in off-diagonal in the parallel rows and columns.

Table 7. Discriminant Validity (Banks’ Employees)

\begin{tabular}{|l|l|l|l|l|l|l|l|l|l|l|}
\hline & 1 & 2 & 3 & 4 & 5 & 6 & 7 & 8 & 9 & 10 \\
\hline $\begin{array}{l}\text { 1.Career } \\
\text { Development }\end{array}$ & 0.919 & & & & & & & & & \\
\hline 2.Co-Workers & 0.543 & 0.910 & & & & & & & & \\
\hline 3.Compensation & 0.576 & 0.588 & 0.821 & & & & & & & \\
\hline $\begin{array}{l}\text { 4.Employee } \\
\text { Performance }\end{array}$ & 0.518 & 0.516 & 0.545 & 0.950 & & & & & & \\
\hline
\end{tabular}




\begin{tabular}{|l|l|l|l|l|l|l|l|l|l|l|}
$\begin{array}{l}\text { 5.Employee } \\
\text { Retention }\end{array}$ & 0.534 & 0.518 & 0.530 & 0.563 & 0.818 & & & & & \\
\hline $\begin{array}{l}\text { 6.Healthcare } \\
\text { Insurance }\end{array}$ & 0.552 & 0.579 & 0.619 & 0.531 & 0.536 & 0.854 & & & & \\
\hline $\begin{array}{l}\text { 7.Increment } \\
\text { And Bonuses }\end{array}$ & 0.527 & 0.663 & 0.548 & 0.504 & 0.517 & 0.573 & 0.821 & & & \\
\hline 8.Promotion & 0.506 & 0.565 & 0.560 & 0.520 & 0.520 & 0.697 & 0.545 & 0.935 & & \\
\hline 9.Supervisor & 0.577 & 0.537 & 0.598 & 0.576 & 0.527 & 0.517 & 0.537 & 0.511 & 0.787 & \\
\hline $\begin{array}{l}\text { 10.Working } \\
\text { Conditions }\end{array}$ & 0.595 & 0.535 & 0.511 & 0.508 & 0.519 & 0.511 & 0.540 & 0.501 & 0.535 & 0.802 \\
\hline
\end{tabular}

Table 8. Discriminant Validity (Educational Institutions’ Employees)

\begin{tabular}{|c|c|c|c|c|c|c|c|c|c|c|}
\hline & 1 & 2 & 3 & 4 & 5 & 6 & 7 & 8 & 9 & 10 \\
\hline $\begin{array}{l}\text { 1.Career } \\
\text { Development }\end{array}$ & 0.726 & & & & & & & & & \\
\hline 2.Co-Workers & 0.541 & 0.895 & & & & & & & & \\
\hline 3.Compensation & 0.587 & 0.522 & 0.869 & & & & & & & \\
\hline $\begin{array}{l}\text { 4.Employee } \\
\text { Performance }\end{array}$ & 0.559 & 0.616 & 0.574 & 0.913 & & & & & & \\
\hline $\begin{array}{l}\text { 5.Employee } \\
\text { Retention }\end{array}$ & 0.512 & 0.578 & 0.432 & 0.633 & 0.864 & & & & & \\
\hline $\begin{array}{l}\text { 6.Healthcare } \\
\text { Insurance }\end{array}$ & 0.552 & 0.532 & 0.501 & 0.521 & 0.585 & 0.857 & & & & \\
\hline $\begin{array}{l}\text { 7.Increment } \\
\text { And Bonuses }\end{array}$ & 0.529 & 0.601 & 0.478 & 0.604 & 0.611 & 0.587 & 0.793 & & & \\
\hline 8.Promotion & 0.531 & 0.625 & 0.554 & 0.620 & 0.490 & 0.592 & 0.592 & 0.773 & & \\
\hline 9.Supervisor & 0.666 & 0.596 & 0.604 & 0.476 & 0.613 & 0.513 & 0.508 & 0.607 & 0.852 & \\
\hline $\begin{array}{l}\text { 10.Working } \\
\text { Conditions }\end{array}$ & 0.545 & 0.614 & 0.544 & 0.567 & 0.574 & 0.524 & 0.498 & 0.543 & 0.672 & 0.763 \\
\hline
\end{tabular}

\subsection{Model Fit Measures}

The fitness of the model in SEM-PLS is defined by various measures such as standardized root-mean-square residual (SRMR), and the exact model fits like d_ULS and d_G, Normed Fit Index (NFI), and $\chi^{2}$ (Chi-square). The model fit measures consisting the measured value 


\section{Macrothink}

of both saturated model as well as the estimated model is reported in above Table. The saturated model assesses the correlation between all constructs. The estimated model, on the other hand, takes model structure into account and is based on total effect scheme.

Table 9. Model Fit

\begin{tabular}{|l|l|l|l|l|}
\hline $\begin{array}{l}\text { Fit Summary } \\
\text { Edu }\end{array}$ & \multicolumn{2}{l}{ Edu } & Banks \\
\hline & \multicolumn{5}{|l}{ Saturated Model } & \multicolumn{2}{l|}{ Estimated Model } \\
\hline SRMR & 0.117 & 0.099 & 0.117 & 0.100 \\
\hline d_ULS & 6.819 & 3.475 & 6.828 & 3.487 \\
\hline d_G & 2.637 & 2.060 & 2.640 & 2.063 \\
\hline Chi-Square & 1267.64 & 1018.858 & 1267.92 & 1019.677 \\
\hline NFI & 0.486 & 0.505 & 0.486 & 0.504 \\
\hline
\end{tabular}

\subsection{Hypothesis Testing}

Bootstrapping is one of the key steps in PLS-SEM, which provides the information of stability of coefficient estimate. In this process, a large number of sub-samples are drawn from the original sample with replacement (Hair et al. 2016). After running the bootstrap routine, SmartPLS shows the t-values for structural model estimates derived from the bootstrapping procedure. The results of path coefficients for all the hypothesis are shown in the following table. The t-value greater than $1.96(\mathrm{p}<.005)$ shows that the relationship is significant at $95 \%$ confidence level $(\alpha=0.05)$. Paths showing whether the relationship between measured and latent variables are significant or not. The path diagram showed in figure $2 \& 3$. 




Figure 2. Education Sector's Employees 


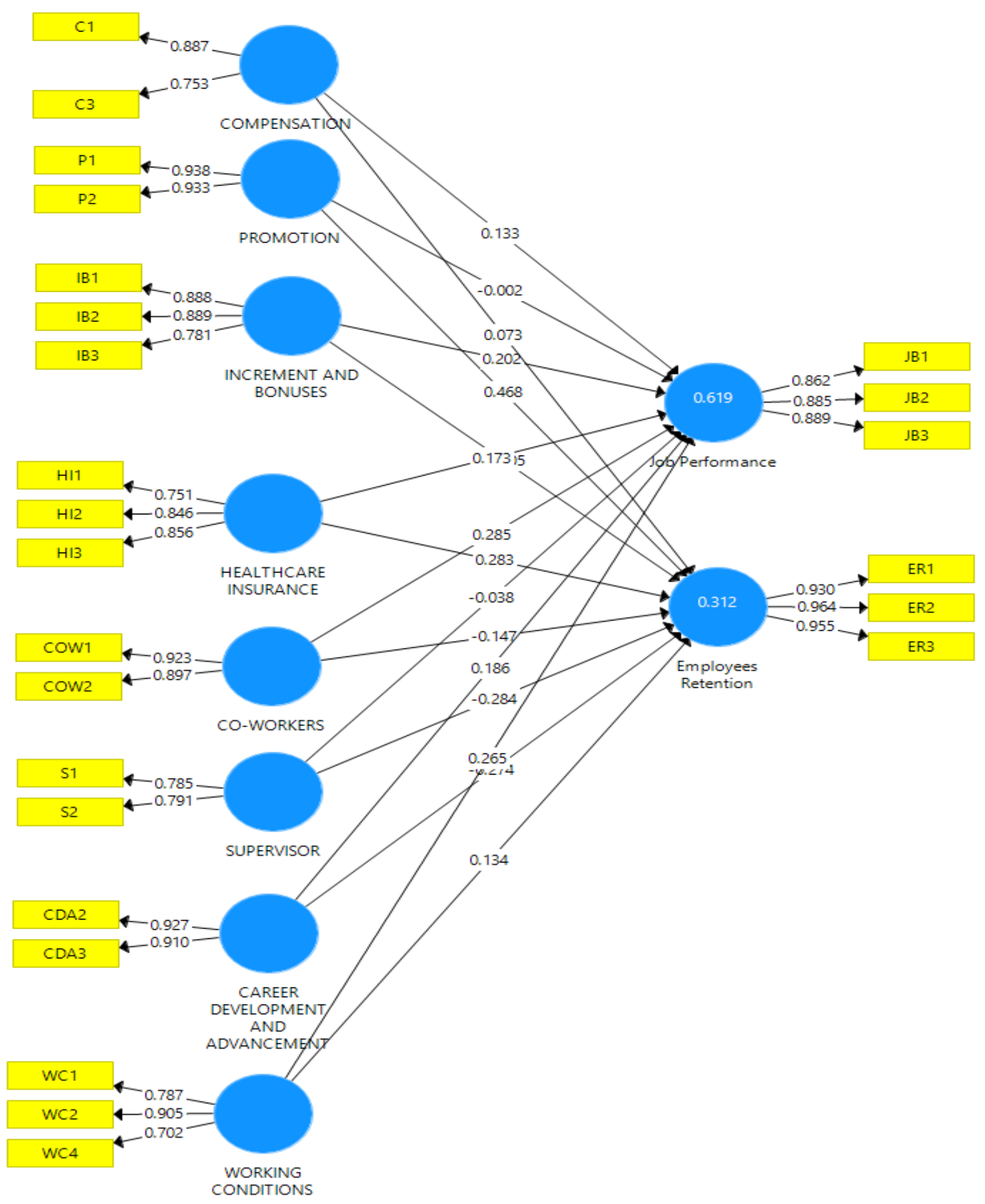

Figure 3. Banking Sector's Employees 
Table 10. Hypotheses

\begin{tabular}{|c|c|c|c|c|}
\hline Sector & \multicolumn{2}{|c|}{ Banks’ Employees } & \multicolumn{2}{|l|}{$\begin{array}{l}\text { Education } \\
\text { Employees }\end{array}$} \\
\hline Hypothesis & $\mathrm{T}$-values & $\begin{array}{l}\mathrm{P} \\
\text {-values }\end{array}$ & $\mathrm{T}$-values & $\mathrm{P}$-values \\
\hline $\begin{array}{l}\text { H1: Career Development has a significant impact on Job } \\
\text { Performance }\end{array}$ & -1.864 & 0.063 & 0.701 & 0.483 \\
\hline $\mathrm{H}_{2}$ : Co-Workers have a significant impact on Job Performance & 4.374 & 0.000 & 3.236 & 0.001 \\
\hline $\begin{array}{l}\mathrm{H}_{3} \text { : Compensations have a significant impact on Job } \\
\text { Performance }\end{array}$ & 1.394 & 0.164 & 0.278 & 0.781 \\
\hline $\begin{array}{l}\mathrm{H}_{4} \text { : Working Condition has a significant impact on Job } \\
\text { Performance }\end{array}$ & 4.405 & 0.000 & 2.136 & 0.033 \\
\hline $\begin{array}{l}\mathrm{H}_{5} \text { : Healthcare Insurance has significant impact on Job } \\
\text { Performance }\end{array}$ & 2.048 & 0.041 & -0.737 & 0.462 \\
\hline $\begin{array}{l}\mathrm{H}_{6} \text { : Increment And Bonuses have a significant impact on Job } \\
\text { Performance }\end{array}$ & 1.987 & 0.047 & -1.440 & 0.151 \\
\hline $\mathrm{H}_{7}$ : Promotion has significant impact on Job Performance & -0.046 & 0.963 & -0.418 & 0.676 \\
\hline $\mathrm{H}_{8}$ : Supervisor has significant impact on Job Performance & -0.764 & 0.445 & 2.269 & 0.024 \\
\hline $\begin{array}{l}\mathrm{H}_{9} \text { : Career Development has a significant impact on employees } \\
\text { retention }\end{array}$ & 2.439 & 0.015 & 0.701 & 0.483 \\
\hline $\begin{array}{l}\mathrm{H}_{10} \text { : Co-Workers have a significant impact on employees } \\
\text { retention }\end{array}$ & 1.222 & 0.222 & -0.814 & 0.416 \\
\hline $\begin{array}{l}\mathrm{H}_{11} \text { : Compensations have a significant impact on employees } \\
\text { retention }\end{array}$ & -0.569 & 0.569 & -0.551 & 0.582 \\
\hline $\begin{array}{l}\mathrm{H}_{12} \text { : Working Condition has a significant impact on employees } \\
\text { retention }\end{array}$ & 1.079 & 0.281 & 1.338 & 0.181 \\
\hline $\begin{array}{l}\mathrm{H}_{13} \text { : Healthcare Insurance has significant impact on employees } \\
\text { retention }\end{array}$ & -2.417 & 0.016 & -2.208 & 0.028 \\
\hline $\begin{array}{l}\mathrm{H}_{14} \text { : Increment And Bonuses have a significant impact on } \\
\text { employees retention }\end{array}$ & -2.381 & 0.018 & -3.339 & 0.001 \\
\hline $\mathrm{H}_{15}$ : Promotion has significant impact on employee's retention & -4.139 & 0.000 & -0.416 & 0.677 \\
\hline $\mathrm{H}_{16}$ : Supervisor has significant impact on Job Performance & -2.121 & 0.034 & 1.626 & 0.105 \\
\hline
\end{tabular}

Above is the table which displays the results of hypothesis, the variables having relationship is positive as the $p$ values of all variables are less than 0.05 which confirms that the variables taken for the study will have a positive impact on the supply chain performance in food industry. The $\mathrm{T}$ value shows there is a significant difference among the variables and the $\mathrm{P}$ 
values depicts the decision no relation has been rejected and the alternative hypothesis have been supported on the basis of $p$ values.

Based on results of table 6 job satisfaction core drivers including Career Development, Compensations and Promotions do not significantly affect the employee's performance in educational as well as banking sector. These relationships are insignificant with $\mathrm{p}$ values > 0.05. This insignificant impact of promotion on employee's performance is also in accordance with some previous researches (Malik et al, 2012). The supervisors do not have a significant impact on employee's performance due to $\mathrm{p}$ value $>0.05$ in banking sector employees but it has significant impact on employees of educational sector due to $\mathrm{p}$ value < 0.05. For supervisor and employee performance, our results show that there is no significant relationship in banking sector employees due to $p$ value $>0.05$ and this also has been an ongoing area of research that whether the employees who are supported by supervisors perform well or the well-performers gets supervisor's support. These researches show that this relationship is under study and is still ambiguous (Christ et al., 2016; Sturman \& Park, 2016). In our study healthcare insurance, increment and bonuses have insignificant impact on employee's performance of the educational sector but in banking sector co-workers, working conditions, healthcare insurance and increment and bonuses have a significant impact on performance of employees. Co-workers can also have a significant impact on left over employee's performance (Anderson \& $\underline{\text { Haas, }}$ 2018). Our results show the same relationship that co-workers have a significant as well as positive impact on employee's performance (banking sector). Working conditions also have a significant impact on employee's performance because better workplace conditions can result in less health issues and employee's performance can increase. Our results are in accordance with the previous studies on this relationship because the better workplace conditions result in less workplace injuries and illnesses (Jinnett, 2017; Baethge, 2015). Healthcare insurance also significantly impacts the employee's performance because the employees need health insurance to perform better (Devaraj \& Patel, 2017) and our results have supported our hypothesis that health care insurance significantly impact employee's performance. Employee's performance is said to have a positive relation with increment and bonuses because the employees become motivated when they get bonuses or increments and in turn, they perform better due to this monetary reward (Kiruja \& Mukuru, 2013; Khalid, 2018). And our study also supports this relationship.

The challenge of employee retention can be best faced keeping in view a number of factors that also include supervisory relationships, rewards and promotion. So, this supports our two hypotheses for banking sector that supervisory support and promotions have significant ( $\mathrm{p}$ value < 0.05) impact on employee's decisions to stay loyal to organization (Cloutier et al., 2015). Healthcare insurance and increment and bonuses have a significant impact on employee retention in both sectors (banking as well as educational). Co-workers, compensation and working conditions do not significantly ( $p$ value $>0.05$ ) impact the employee's retention in banking as well as educational sector and it can be seen that previous literature supports this relationship. Co-workers do not have significant ( $\mathrm{p}$ value $>0.05$ ) 
relationship with employee retention if the relationships are not good enough. It solely depends on whether both of them were having good relationships or bad (Anderson \& $\underline{\text { Haas }}$, 2018). In our study, career development, health care insurance and increment $\&$ bonuses have significant ( $\mathrm{p}$ value $>0.05$ ) positive relationship with employee retention in banking sector which implies that employees decide to remain loyal to the organization. Our study shows that career development and promotion have insignificant ( $\mathrm{p}$ value >0.05) impact on employee's retention in educational sector employees but impact is significant in banking sector employees. This is also supported by the previous literature that if employees are provided with health care insurance programs, career development practices and quarterly or biannually bonuses, they tend to stay loyal to organization (Campion et al., 2018; Humphreys, 2009; Law, 2016; Mathieu et al, 2016).

\section{Conclusion}

Better workplace conditions tend to significantly impact the employee performance in banking as well as educational sector. Different researches are in line with our results that not only cognitive but physical demands also play an important role in employee performance and these needs should be kept in mind at time of hiring. This is because the bad workplace conditions can cause episodes of illness and injuries with in employees that can in turn affect their productivity and performance. Human capital theory also suggests the same that when employers invest in health of employees, it can bring them improved work quality (Jinnett et al., 2017). We can conclude and our results shows the same that better workplace conditions for both sector employees (banking and educational) can result in better performances of the employees (Baethge et al., 2015). Co-workers also have significant impact on employee's performance of both sectors. Career development, compensations and promotions have insignificant impact on employee's performance of both sectors. This implies that organizations must not invest a lot of their time or resources in these three.

As far as employee's retention is considered, co-workers, compensations and working conditions do not have a significant impact on retention of employees hence we can conclude that these factors do not contribute to employee's decision of staying loyal to organization. However, health care insurance and increment \& Bonuses both have positive impact on employee's retention in both sectors so we can conclude from results that a focus is needed in these two factors so that employee's retention can be increased.

\subsection{Recommendations}

Managers of the banking and educational sector must focus on the co-workers and working conditions so that employee's performance can be enhanced. A safety investment strategy can help the employers to get better workplace conditions and hence they can increase employee's performance (Jinnett, 2017) in banking and educational sectors. This is because better workplace conditions help in eradication of workplace injuries. Managers must also work on relationship management among their subordinates as Co-workers also have an impact on the performance (Anderson \& $\underline{\text { Haas }}, 2018$ ). However, employee retention cannot be 
altered by improving work conditions. So, for analyzing turn over intentions, manager must consider some other factors that can help them to understand why employees may or may not remain loyal to organizations. For retention in banking and educational sector, managers can focus on increment $\&$ bonuses and health care insurance programs because they can help them to retain their employees. However, they can also focus on promotion plans for banking sector employees (Cloutier et al., 2015). Educational sector employees have no relationship of promotion with retention. Managers in banking sector must also invest their time and resources in arranging career development programs because there can be seen a significant relationship between retention and career development. Educational sector employees cannot be retained through development programs neither they can be retained by the co-worker's behaviors and attitudes. However, banking sector employees' needs health care insurance, career developments and bonuses to enhance employee retention (Campion et al., 2018; Humphreys, 2009; Law, 2016; Mathieu et al, 2016).

\section{Acknowledgement}

First and foremost praises and thanks to almighty"Allah" who showers his blessings on me. Then I would like to express my special thanks to my supervisor Dr. Danish Ahmed Siddiqui for giving me the opportunity to work under his guidance and provide invaluable advice and expertise throughout my work.

Nobody is more important in pursuit of this thesis other than my parents, Muhammad Zafar ul Islam Qadri and Mrs. Salma Zafar. I am very grateful to both of them and their love, prayers and continuing support in completing this thesis.

My profound gratitude and sincere thanks to Dr. Fahad Azim for valuable guidance and constant encouragement and untiring help which has been source of inspiration throughout my work.

\section{References}

Ahammad, M. F., Tarba, S. Y., Liu, Y., \& Glaister, K. W. (2016). Knowledge transfer and cross-border acquisition performance: The impact of cultural distance and employee retention. International Business Review, 25(1), 66-75.

Alegre, I., Mas-Machuca, M., \& Berbegal-Mirabent, J. (2016). Antecedents of employee job satisfaction: Do they matter? Journal of Business Research, 69(4), 1390-1395.

Anderson, T., \& Martine Haas, M. (2018). My colleague just left! How the mobility of co-workers affects job performance. Academy of Management Proceedings, 1.

Andrew F. Hayes (2013). Introduction to Mediation, Moderation, and Conditional Process Analysis: A Regression-Based Approach. New York, NY: The Guilford Press

Angerer, P., \& Weigl, M. (2015). Physicians' Psychosocial Work Conditions and Quality of Care: A Literature Review. Professions and Professionalism, 5(1). 
Ashton, A. S. (2017). How human resources management best practice influence employee satisfaction and job retention in the Thai hotel industry. Journal of Human Resources in Hospitality \& Tourism, 17(2), 175-199.

Assoc. Prof. Nilgün Avci (2017). The Relationship between Coworker Supports, Quality of Work Life And Wellbeing: An Empirical Study Of Hotel Employees. Uluslararası Yönetim İktisat Ve İşletme Dergisi, Cilt 13, Sayı 3, 2017 Int. Journal of Management Economics and Business, 13(3), 2017。

Baethge, A., Müller, A., \& Rigotti, T. (2015). Nursing performance under high workload: a diary study on the moderating role of selection, optimization and compensation strategies. Journal of Advanced Nursing, 72(3), 545-557.

Barnay, T. (2015). Health, work and working conditions: a review of the European economic literature. The European Journal of Health Economics, 17(6), 693-709.

Baron, R. M., \& Kenny, D. A. (1986). The moderator-mediator variable distinction in social psychological research: Conceptual, strategic, and statistical considerations. Journal of Personality and Social Psychology, 51, 1173-1182.

Behrman, J.R., Parker, S.W., Todd, P.E., Wolpin, K.I. (2015). Aligning learning incentives of students and teachers: results from a social experiment in Mexican high schools. Journal of Political. Economics, 123(2), 325-364.

Belzil, C., Bognanno, M., \& Poinas, F. (2018). Promotion Determinants in Corporate Hierarchies: An Examination of Fast Tracks and Functional Area. Transitions through the Labor Market, 73-106.

Bodjrenou Kossivi, Ming, X., \& Bomboma Kalgora (2016). Study on Determining Factors of Employee Retention. Scientific Research Publishing.

Breevaart, K., Bakker, A. B., Demerouti, E., \& Derks, D. (2015). Who takes the lead? A multi-source diary study on leadership, work engagement, and job performance. Journal of Organizational Behavior, 37(3), 309-325.

Bussin, M. (2018). Reward Solutions to Retention Questions. Psychology of Retention, 395-413.

Campion, E. D., Campion, M. C., \& Campion, M. A. (2018). Best Practices in Incentive Compensation Bonus Administration Based on Research and Professional Advice. Compensation \& Benefits Review.

Carmines, E. G., \& Zeller, R. A. (1979). Reliability and Validity Assessment (Vol. 17). Thousand Oaks, CA: Sage. https://doi.org/10.4135/9781412985642

Chin, C. L. (2018). The Influence of Job Satisfaction on Employee Turnover Intention in the Manufacturing Industry of Malaysia. Journal of Arts \& Social Sciences, 1(2), 53-63. 
Chong, V. K., \& Law, M. B. C. (2016). The effect of a budget-based incentive compensation scheme on job performance. Journal of Accounting \& Organizational Change, 12(4), $590-613$.

Christ, M. H., Emett, S. A., Tayler, W. B., \& Wood, D. A. (2016). Compensation or feedback: Motivating performance in multidimensional tasks. Accounting, Organizations and Society, 50, 27-40.

Cloutier, O., Felusiak, L., Hill, C., \& Jones, E. J. P. (2015). The Importance of Developing Strategies for Employee Retention. Journal of Leadership, Accountability and Ethics, 12(2).

Cronbach, L. J., \& Shavelson, R. J. (2004) My Current Thoughts on Coefficient Alpha and Successor Procedures. Educational and Psychological Measurement, 64, 391-418. https://doi.org/10.1177/0013164404266386

David, M. M., \& Joseph, O. (2015). Effects of Pay and Work Environment on Employee Retention: A Study of Hotel Industry in Mombasa County. International Journal of Scientific and Research Publications, 5(4), April 20151 ISSN 2250-315.

Dawson, C., Veliziotis, M., \& Hopkins, B. (2014). Temporary employment, job satisfaction and subjective well-being. Economic and Industrial Democracy, 38(1), 69-98.

Devaraj, S., \& Patel, P. C. (2017). Health insurance and employee productivity: Findings from the 2007 Survey of Business Owners'. Economics Bulletin, 37(2),1351-1364.

Do, T. T. (2018). How spirituality, climate and compensation affect job performance. Social Responsibility Journal, 14(2), 396-409.

Draghi, M. (2017). Introductory statement to the press conference, President of the ECB, $\begin{array}{llll}\text { Frankfurtam } & \text { Main, } & 9 & \text { March }\end{array}$ https://www.ecb.europa.eu/press/pressconf/2017/html/is170309.en.html

Edith W. M. Gathungu, Mike A. Iravo, \& Namusonge, G. S. (2015). Effect of Promotion Strategies on the Organizational Commitment of Banking Sector Employees in Kenya. IOSR Journal Of Humanities And Social Science (IOSR-JHSS), 20(10), Ver. I (Oct. 2015), 36-45.

F. P. Dickson (June 1973). Backed Blades and Points. https://doi.org/10.1111/j.1835-9310.1973.tb01368.x

Falk, J., \& Karamcheva, N. (2018). Comparing the Effects of Current Pay and Defined Benefit Pensions on Employee Retention.

Fornell, C., \& Larcker, D. F. (1981). Evaluating Structural Equation Models with Unobservable Variables and Measurement Error. Journal of Marketing Research, 18(1), 39-50.

Froese, F. J., Peltokorpi, V., Varma, A., \& Hitotsuyanagi-Hansel, A. (2018). Merit-based Rewards, Job Satisfaction and Voluntary Turnover: Moderating Effects of Employee Demographic Characteristics. British Journal of Management. 
Furunes, T., Mykletun, R. J., Einarsen, S., \& Glas $\varnothing$, L. (2015). Do Low-quality Leader-Member Relationships Matter for Subordinates? Evidence from Three Samples on the Validity of the Norwegian LMX Scale. Nordic Journal of Working Life Studies, 6(2), 71-87.

Gemma, D., Anna, T., \& Christine, C. (2014). From end user to provider: making sense of becoming a peer support worker using interpretative phenomenological analysis. Journal of Public Mental Health, 13(2), 2014.

Greckhamer, T. (2015). CEO compensation in relation to worker compensation across countries: The configurational impact of country-level institutions. Strategic Management Journal, 37(4), 793-815.

Gul, H., Usman, M., Liu, Y., Rehman, Z., \& Jebran, K. (2018). Does the effect of power distance moderate the relation between person environment fit and job satisfaction leading to job performance? Evidence from Afghanistan and Pakistan. Future Business Journal, 4(1), 68-83.

Gutermann, D., Lehmann-Willenbrock, N., Boer, D., Born, M., \& Voelpel, S. C. (2017). How Leaders Affect Followers' Work Engagement and Performance: Integrating Leader-Member Exchange and Crossover Theory. British Journal of Management, 28(2), 299-314.

Hair Jr, Joseph F., G. Tomas, M. Hult, Christian Ringle, \& Marko, S. (2016). A Primer on Partial Least Squares Structural Equation Modeling (PLS-SEM). Thousand Oaks, CA: Sage

Hair, J. F., Black. W. C., Babin. B. J., \& Anderson. R. E. (2010), Multivariate Data Analysis, 7th ed. Pearson Prentice Hall, New Jersey.

Hsieh, J. Y. (2016). Spurious or True? An Exploration of Antecedents and Simultaneity of Job Performance and Job Satisfaction Across the Sectors. Public Personnel Management, 45(1), 90-118.

Hsieh, Y. C., Apostolopoulos, Y., \& Sönmez, S. (2015). Work Conditions and Health and Well-Being of Latina Hotel Housekeepers. Journal of Immigrant and Minority Health, 18(3), $568-581$.

Humphreys, J., Wakerman, J., Kuipers, P., Wells, B., Russell, D., Siegloff, S., \& Homer, K. (2009). Improving Workforce Retention: Developing an Integrated Logic Model to Maximize Sustainability of Small Rural \& Remote Health Care Services.

Iqra Saeed, momina waseem, Sidra, S., \& Muhammad, R. (2014). The relationship of Turnover intention with job satisfaction, job performance, Leader member exchange, Emotional intelligence and organizational commitment. International Journal of Learning \& Development, $4(2)$.

Jadon, P. S, \& Upadhyay. (2018). Employee Retention in Public and Private Hospital Settings: An Empirical Study of Its Relationship with Participative Climate, And Role Performance. Indian Journal of Commerce \& Management Studies, 9(1). 
Janet Yellen (March 27, 2015) Normalizing Monetary Policy: Prospects and Perspectives: a speech at the "The New Normal Monetary Policy," a research conference sponsored by the Federal Reserve Bank of San Francisco, San Francisco, California. Econpapers

Jennifer Nageli Koitalek (2016). Influence Of Compensation policy On Employee Commitment at Teachers Service Commission In Kenya.

Jinnett, K., Schwatka, N., Tenney, L., Brockbank, C. v. S., \& Newman, L. S. (2017). Chronic Conditions, Workplace Safety, And Job Demands Contribute to Absenteeism and Job Performance. Health Affairs, 36(2), 237-244.

Jones, M. K., Latreille, P. L., \& Sloane, P. J. (2016). Job Anxiety, Work-Related Psychological Illness and Workplace Performance. British Journal of Industrial Relations, 54(4), 742-767.

Judge, T. A., \& Kammeyer-Mueller, J. D. (2012). Job attitudes. Annual Review of Psychology, 63, 341-367.

Karikari, A. F., Opoku Boadi, P., \& Sai, A. A. (2018). Rewarding employees for corporate performance improvements. Human Systems Management, 37(3), 311-317. doi:10.3233/hsm-17186

Kiruja, E. K., \& Elegwa, M. (2013). Effect of Motivation on Employee Performance In Public Middle Level Technical Training Institutions In Kenya. International Journal of Advances in Management and Economics.

Komal, K., \& Samina, N. (2018). Employee Participation and Employee Retention in View of Compensation. SAGE Open, October-December 2018: 1-17 (c) The Author(s) 2018, DOI: 10.1177/2158244018810067, journals.sagepub.com/home/sgo

Lai, W. H. (2011). Willingness-to-engage in technology transfer in industry-university collaborations. Journal of Business Research.

Law, C. C. H. (2016). Using bonus and awards for motivating project employees. Human Resource Management International Digest, 24(7), 4-7.

Lazear, E. P. (2018). Compensation and Incentives in the Workplace. Journal of Economic Perspectives, 32(3), 195-214.

LePine, M. A., Zhang, Y., Crawford, E. R., \& Rich, B. L. (2016). Turning their Pain to Gain: Charismatic Leader Influence on Follower Stress Appraisal and Job Performance. Academy of Management Journal, 59(3), 1036-1059.

Malik, M. E., Danish, R. Q., \& Munir, Y. (2012). The Impact of Pay and Promotion on Job Satisfaction: Evidence from Higher Education Institutes of Pakistan. American Journal of Economics, Special Issue, 6-9. 
Mansour, M. (2016). Quantifying the intangible costs related to non-ergonomic work conditions and work injuries based on the stress level among employees. Safety Science, 82, 283-288.

Marx, K. (1867-1883), Capital. Critique of Political Economy. (1 ed.). Hamburg: Verlag von Otto

Masa'deh, R., Shannak, R., Maqableh, M., \& Tarhini, A. (2017). The impact of knowledge management on job performance in higher education. Journal of Enterprise Information Management, 30(2), 244-262.

Mathieu, C., Fabi, B., Lacoursière, R., \& Raymond, L. (2016). The role of supervisory behavior, job satisfaction and organizational commitment on employee turnover. Journal of Management \& Organization, 22(1), 113-129.

Mehmet Kahya, Faruk Şahin, (2018). The effect of leader personality on follower behaviour: The mediating role of leader-member exchange. Leadership \& Organization Development Journal, 39(1), 14-33, https://doi.org/10.1108/LODJ-08-2016-0206

Mizuno, M., Yamada, Y., Iwaasa, T., Togashi, E., Suzuki, M., \& Mizuno, Y. (2018). Retention Management of Nurses: A Case of University Hospital in Japan. Proceedings of the 20th Congress of the International Ergonomics Association (IEA 2018), 422-428.

Owens, B. P., Baker, W. E., Sumpter, D. M., \& Cameron, K. S. (2016). Relational energy at work: Implications for job engagement and job performance. Journal of Applied Psychology, 101(1), 35-49.

Pasimeni, P. (2018). The relation between productivity and compensation in Europe.

Patrick, E. S., \& Niall, B. (2002). Mediation in Experimental and Non-experimental Studies: New Procedures and Recommendations. by the American Psychological Association, Inc. 2002, Vol. 7, No. 4, 422-445 1082-989X/02/\$5.00 DOI: 10.1037//1082-989X.7.4.422

Peng, J., Li, D., Zhang, Z., Tian, Y., Miao, D., Xiao, W., \& Zhang, J. (2014). How can core self-evaluations influence job burnout? The key roles of organizational commitment and job satisfaction. Journal of Health Psychology, 21(1), 50-59.

Ricardo, 1911 [1817], p. 1 in 1911 edition) (Ricardo opening paragraph of his book On the Principles of Political Economy and Taxation (1817).

Safarpour, H., Sabzevari, S., \& Delpisheh, A. (2018). A Study on the Occupational Stress, Job Satisfaction and Job Performance among Hospital Nurses in Ilam, Iran.

Shah, M. M., Mohd, I. H., \& Khairudin, M. K. (2018). Factors Relating to Employee Engagement: A Case Study in a Selected Bank. In F. Noordin, A. K. Othman, \& E. S. Kassim (Eds.), Proceedings of the 2nd Advances in Business Research International Conference (pp. 297-303). Singapore: Springer Singapore. https://doi.org/10.1007/978-981-10-6053-3_28 
Sharma, J., \& Dhar, R. L. (2016). Factors influencing job performance of nursing staff. Personnel Review, 45(1), 161-182.

Singh, P., \& Masters, W. A. (2018). Performance bonuses in the public sector: Winner-take-all prizes versus proportional payments to reduce child malnutrition in India. Journal of Development Economics.

Smith, A. (1776). The Wealth of Nations, Book 1, Chapter 8 "Of the Wages of Labor "Yellen, Janet. Semiannual Monetary Policy Report to the Congress. February 24, 2015; http://www.federalreserve.gov/newsevents/testimony/yellen20150224a.htm.

Sturman, M. C., \& Park, S. (2016). The changing relationship between supervisors and subordinates: How managing this relationship evolves over time. Cornell Hospitality Report, 16(13), 3-8.

Tanwar, K., \& Prasad, A. (2016). Exploring the Relationship between Employer Branding and Employee Retention. Global Business Review, 17(3), 186-206.

Tejeda, M. J. (2014). Exploring the Supportive Effects of Spiritual Well-Being on Job Satisfaction Given Adverse Work Conditions. Journal of Business Ethics, 131(1), 173-181.

Theorell, T., Hammarström, A., Aronsson, G., Träskman Bendz, L., Grape, T., Hogstedt, C., Hall, C. (2015). A systematic review including meta-analysis of work environment and depressive symptoms. BMC Public Health, 15(1).

Thomas, G., Martin, R., \& Riggio, R. E. (2013). Leading Groups: Leadership as a Group Process. Group Processes \& Intergroup Relations, 16, 3-16. http://dx.doi.org/10.1177/1368430212462497

Waiyaki, Elizabeth Wairimu Waiyaki (2017). Effect Of Motivation On Employee Performance: A Case Of Pam Golding Properties Limited, Nairobi.

Williams, C. (2007). Research Methods. Journal of Business \& Economics Research, 5(3).

Zacher, H., Chan, F., Bakker, A. B., \& Demerouti, E. (2015). Selection, optimization, and compensation strategies: Interactive effects on daily work engagement. Journal of Vocational Behavior, 87, 101-107.

\section{Copyright}

Copyright for this article is retained by the author(s), with first publication rights granted to the journal.

This is an open-access article distributed under the terms and conditions of the Creative Commons Attribution license (http://creativecommons.org/licenses/by/4.0/). 